ASIMTOT: JURNAL KEPENDIDIKAN MATEMATIKA

Volume 3 Nomor 2, Juni - November 2021, halaman 125 - 135

Tersedia Daring pada https://journal.unwira.ac.id/index.php/ASIMTOT

\title{
PENGARUH PERSEPSI SISWA TENTANG GURU MATEMATIKA TERHADAP MOTIVASI BELAJAR MATEMATIKA SISWA
}

\section{THE EFFECT OF STUDENTS' PERCEPTION ABOUT MATHEMATICS TEACHER ON STUDENTS'MATHEMATICS LEARNING MOTIVIATION}

\author{
Patrisius Afrisno Udil ${ }^{1}$, Yohanes Lupa Bole ${ }^{2}$, Christine K. Ekowati ${ }^{3}$ \\ ${ }^{1,2,3}$ Pendidikan Matematika, FKIP, Universitas Nusa Cendana \\ Afrisno.udil@staf.undana.ac.id, yohanesbole@gmail.com
}

\begin{abstract}
Abstrak: Penelitian ini bertujuan untuk mengetahui pengaruh persepsi siswa tentang guru matematika terhadap motivasi belajar matematika siswa kelas VIII SMP Negeri 5 Kupang Tengah. Penelitian ini termasuk dalam penelitian kuantitatif dengan regresi linear sederhana. Penelitian dilakukan di SMP Negeri 5 Kupang tengah pada bulan Juni 2021. Populasi pada penelitian ini adalah siswa kelas VIII SMP Negeri 5 Kupang Tengah Penfui Timur Kabupaten Kupang. Sampel dalam penelitian ini berjumlah 30 siswa yang diperoleh melalui metode simple random sampling. Instrumen yang digunakan antara lain angket persepsi siswa tentang guru matematika dan angket motivasi belajar matematika. Analisis data dilakukan secara inferensial dengan menggunakan SPSS 25. Hasil penelitian menunjukan bahwa adanya hubungan yang kuat dan positif antara persepsi siswa tentang guru matematika dan motivasi belajar matematika. Hal ini terlihat dari koefisien korelasi yang bernilai 0.702. Lebih lanjut ditemukan adanya pengaruh yang signifikan antara persepsi siswa tentang guru matematika terhadap motivasi belajar matematika yang ditunjukkan oleh nilai $F_{\text {hitung }}$ sebesar 27.210 yang lebih besar dari $\mathrm{F}_{\text {tabel }}=4.20$ dengan taraf signifikansi $\alpha=5 \%$. Hal ini juga dipertegas oleh nilai sig. ( $p$-value) $0.000<\alpha$.
\end{abstract}

Kata Kunci: persespsi, motivasi, persepsi siswa tentang guru matematika, motivasi belajar matematika

\begin{abstract}
This research aimed to determine the effect of students' perceptions about mathematics teachers on the mathematics learning motivation of eighth grade students of SMP Negeri 5 Kupang Tengah. This research is quantitative research with simple linear regression. It was conducted in SMPN 5 Kupang on June 2021. The population of this research is all of $8^{\text {th }}$ graders in SMPN 5 Kupang Tengah, with the sample consist of 30 students chosen with simple random sampling method. The instruments used include a questionnaire on students' perceptions about mathematics teachers and a questionnaire on motivation to learn mathematics. Data analysis was carried out inferentially using SPSS 25. The results showed that there was a strong and positive relationship between students' perceptions of mathematics teachers and their motivation to learn mathematics. It is indicated by the correlation coefficient which is 0.702. Furthermore, it was found that there was a significant effect between students' perceptions of mathematics teachers on mathematics learning motivation, which was indicated by the $F_{\text {count }}=27.210>F_{\text {table }}=4.20$ with a significance level of $=5 \%$. This is also confirmed by the value of sig. (p-value) $0.000<\alpha$.
\end{abstract}

Keywords: perception, motivation, students' perception about mathematics teacher, mathematics learning motivation

Cara Sitasi: Udil, P.A., Bole, Y. L., \& Ekowati, C.K. (2021). Pengaruh Persepsi Siswa tentang Guru Matematika terhadap Motivasi Belajar Matematika Siswa Kelas VIII SMPN 5 Kupang Tengah. Asimtot: Jurnal Kependidikan Matematika, "3”(“2”), "125-135” 
ASIMTOT: JURNAL KEPENDIDIKAN MATEMATIKA

Volume 3 Nomor 2, Juni - November 2021, halaman 125 - 135

Tersedia Daring pada https://journal.unwira.ac.id/index.php/ASIMTOT

Matematika merupakan ilmu universal yang mendasari perkembangan teknologi modern. Matematika mempunyai peran penting dalam berbagai disiplin ilmu dan memajukan daya pikir manusia. Perkembangan pesat di bidang teknologi informasi dan komunikasi dewasa ini tidak lepas dari hasil perkembangan matematika. Untuk menguasai dan menciptakan teknologi di masa depan diperlukan penguasaan matematika yang kuat sejak dini. Pembelajaran matematika diharapkan dapat berperan dalam menyiapkan, meningkatkan dan membekali individu dan masyarakat di era yang penuh perubahan.

Adapun faktor-faktor yang mempengaruhi keberhasilan proses belajar mengajar matematika terdiri dari faktor internal dan faktor eksternal. Dalam hal ini faktor internal terkait dengan semua faktor yang berasal dari dalam diri siswa sendiri, sementara faktor eksternal adalah faktor yang berasal dari luar diri siswa. Salah satu faktor internal keberhasilan belajar siswa adalah motivasi belajar. Motivasi dapat dikatakan sebagai keseluruhan daya penggerak di dalam diri siswa yang menimbulkan kegiatan belajar, yang menjamin kelangsungan dari kegiatan belajar dan yang memberikan arah pada kegiatan belajar, sehingga tujuan yang dikehendaki oleh subjek belajar itu dapat tercapai (Sardiman, 2012). Bagi siswa, motivasi belajar itu penting untuk menyadarkan kedudukan pada awal belajar, proses, dan hasil akhir, menginformasikan tentang kekuatan usaha belajar, mengarahkan kegiatan serta menambah semangat belajar. Lebih lanjut, Razak (2016) juga menegaskan bahwa motivasi dapat menunjang dan mendukung siswa dalam upaya menguasai materi yang pada akhirnya memungkinkan adanya peningkatan hasil belajar. Motivasi belajar juga penting diketahui oleh seorang guru. Pengetahuan dan pemahaman tentang motivasi belajar pada siswa bermanfaat bagi guru (Sardiman, 2012). Dengan demikian, motivasi belajar matematika dapat dipandang sebagai daya penggerak dari dalam diri siswa yang menimbulkan dorongan untuk belajar, memahami, dan menguasi materi matematika yang dipelajari.

Salah satu faktor yang mempengaruhi motivasi belajar matematika siswa yaitu persepsi siswa tentang guru matematika. Proses belajar mengajar tentu saja melibatkan interaksi antara guru dan siswa sehingga akan menimbulkan persepsi siswa terkait dengan penglihatannya terhadap guru tersebut. Sikap dan perilaku guru yang menyenangkan menurut siswa, akan menimbulkan persepsi positif dalam diri siswa yang memungkinkan motivasi belajar siswa meningkat dan berujung pada peningkatan prestasi belajar juga (Indiati, dkk., 2011). Sebaliknya, jika siswa berpersepsi bahwa gurunya tidak disiplin, kasar, kurang mampu membelajarkan materi dengan baik, atau secara umum dipersepsikan kurang baik maka kemungkinan besar siswa akan menunjukkan sikap dan perilaku yang kurang baik juga.

Najichun dan Winarso (2016) mendefinisikan persepsi sebagai salah satu aspek psikologi yang penting bagi manusia dalam merespon kehadiran berbagai aspek dan gejala di sekitarnya. Menurut Sommeng (Ahmadi, 2017), persepsi merupakan suatu 
ASIMTOT: JURNAL KEPENDIDIKAN MATEMATIKA

Volume 3 Nomor 2, Juni - November 2021, halaman 125 - 135

Tersedia Daring pada https://journal.unwira.ac.id/index.php/ASIMTOT

proses yang didahului oleh proses penginderaan, yaitu merupakan proses diterimanya stimulus oleh individu melalui alat indera atau juga disebut proses sensoris. Namun proses ini tidak berhenti begitu saja, melainkan stimulus tersebut diteruskan dan proses selanjutnya merupakan proses persepsi. Karena itu proses persepsi tidak lepas dari proses penginderaan yang merupakan proses pendahulu dari proses persepsi. Dalam konteks pembelajaran, persepsi dapat dipandang sebagai proses kognitif yang menghasilkan pandangan, pendapat, dan respon terkait aktivitas pembelajaran yang diikuti siswa sebagai akibat dari informasi dan pengalaman yang diinderai atau dialami (Udil, 2020). Dengan demikian, persepsi siswa tentang guru matematika dapat dipahami sebagai sebuah kesan, penilaian, dan pendapat siswa tentang performa guru matematika berdasarkan interpretasi siswa terhadap pengalaman yang dialami dalam aktivitas pembelajaran matematika.

Persepsi masing-masing siswa terhadap guru matematika tidaklah selalu sama. Hal ini dikarenakan karakter, cara berfikir dan latar belakang keluarga dan pengalaman masa lalu siswa berbeda-beda. Persepsi yang baik terhadap guru membuat siswa senang dan antusias mengikuti pembelajaran sehingga akan menunjang hasil belajarnya. Sebaliknya, persepsi yang kurang baik akan membentuk motivasi yang kurang baik pula dalam belajar. Dalam hal ini, dapat dikatakan bahwa persepsi siswa tentang guru matematika dapat membentuk/mempengaruhi sikap siswa terhadap proses pembelajaran matematika yang diikutinya (Oginni, Fadiji, and Oginni, 2020). Oleh karena itu, persepsi siswa tentang guru perlu menjadi perhatian guru matematika sehingga dapat menempatkan diri dan mendesain proses pembelajaran yang memungkinkan terbentuknya persepsi siswa yang positif.

Beberapa penelitian terdahulu terkait persepsi dan motivasi belajar matematika telah dilakukan. Sahidin dan Jamil (2013) menemukan dalam penelitiannya bahwa persepsi dan motivasi secara simultan maupun parsial memiliki pengaruh positif yang signifikan terhadap hasil belajar matematika siswa. Syaripah (2016) dalam penelitiannya menemukan bahwa adanya pengaruh yang signifikan antara persepsi pembelajaran matematika terhadap motivasi belajar siswa dalam bidang matematika. Sementara Najichun dan Winarso (2016) dalam penelitiannya menemukan bahwa tidak terdapat hubungan (korelasi) yang signifikan antara persepsi tentang guru matematika dengan prestasi belajar matematika siswa. Beberapa penelitian terdahulu di atas bertujuan untuk mengungkap dan mengetahui hubungan dan pengaruh variabel seperti persepsi, motivasi, dan prestasi belajar matematika siswa. Dalam penelitian ini, peneliti fokus untuk terlebih dahulu mengungkap hubungan dan pengaruh antara persepsi siswa tentang guru terhadap motivasi belajar matematika. Dalam hal ini, peneliti berupaya untuk mempertimbangkan variabel persepsi terhadap guru matematika sebagai salah satu variabel yang penting diperhatikan dalam membentuk motivasi belajar siswa yang kemudian dapat membentuk dorongan 
ASIMTOT: JURNAL KEPENDIDIKAN MATEMATIKA

Volume 3 Nomor 2, Juni - November 2021, halaman 125 - 135

Tersedia Daring pada https://journal.unwira.ac.id/index.php/ASIMTOT

dalam diri siswa untuk berproses dan berprestasi dalam konteks pembelajaran matematika.

Berangkat dari hal tersebut, penelitian dan kajian terkait pengaruh persepsi siswa tentang guru matematika terhadap motivasi dipandang perlu dilakukan sehingga dapat memberikan potret empirik terkait hubungan persepsi dan motivasi. Adapun penelitian ini bertujuan untuk mengetahui ada tidaknya pengaruh yang signifikan antara persepsi siswa tentang guru matematika terhadap motivasi belajar matematika. Penelitian ini diharapkan memberikan masukan bagi perkembangan ilmu pengetahuan khususnya dibidang pendidikan dan bahan masukan dalam meningkatkan kreativitas guru untuk menumbuhkan motivasi belajar pada diri siswa.

\section{Metode Penelitian}

Jenis penelitian yang digunakan dalam penelitian ini adalah penelitian kuantitatif yang bertujuan untuk menemukan ada dan tidaknya hubungan antara dua atau lebih variabel, dan apabila ada, seberapa erat hubungan itu, serta berarti tidaknya hubungan tersebut (Arikunto, 2010). Pendekatan yang digunakan dalam penelitian ini yaitu pendekatan Ex Post Facto, karena variabel bebasnya tidak dikendalikan, dalam arti variabel tersebut telah terjadi. Ex Post Facto yaitu suatu penelitian ilmiah yang penelitiannya tidak dapat secara langsung memanipulasi dan mengendalikan satu atau lebih variabel bebas serta mengamati variabel terikat untuk melihat perbedaan yang sesuai dengan manipulasi variabel tersebut (Arikunto, 2010). Adapun dalam penelitian ini, terdapat satu variabel bebas yaitu persepsi siswa tentang guru matematika dan satu variabel terikat yaitu motivasi belajar matematika.

Penelitian ini dilakukan pada SMP Negeri 5 Kupang Tengah pada bulan Juni 2021. Populasi dalam penelitian ini adalah siswa kelas VIII SMP Negeri 5 Kupang Tengah berjumlah 41 orang. Untuk mendapatkan sampel dari populasi yang representatif maka sampel dipilih menggunakan teknik simple random sampling dimana pengambilan sampel dari populasi secara acak tanpa memperhatikan strata tingkatan karena anggota populasi dianggap homogen (Sugiyono, 2013). Dalam penelitian ini peneliti mengambil sampel sebanyak 30 orang.

Instrumen dalam penelitian ini terdiri dari Angket Persepsi Siswa tentang Guru Matematika dan Angket Motivasi Belajar Matematika yang masing-masing terdiri dari 20 butir item pernyataan. Kedua instrumen dikembangkan oleh peneliti berdasarkan indikator masing-masing variabel yang dirumuskan dari kajian teori terkait persepsi dan motivasi belajar.

Indikator pada angket persepsi siswa tentang guru matematika dikembangkan berdasarkan beberapa pendapat ahli terdahulu (Najichun \& Winarso, 2016; Ahmadi, 2017; Udil, 2020), yang meliputi aspek pengetahuan dengan indikator (1) pengetahuan siswa tentang penampilan guru saat mengajar, (2) pengetahuan siswa tentang perilaku guru saat mengajar; aspek pengharapan dengan 
ASIMTOT: JURNAL KEPENDIDIKAN MATEMATIKA

Volume 3 Nomor 2, Juni - November 2021, halaman 125 - 135

Tersedia Daring pada https://journal.unwira.ac.id/index.php/ASIMTOT

indikator

\author{
(3)
}

pengharapan

tentang penyampaian materi oleh guru, (4) pengharapan tentang pegorganisasian kelas oleh guru, (5) pengharapan tentang evaluasi hasil belajar; dan aspek penilaian dengan indikator (6) penilaian tentang penyampaian materi oleh guru, (7) penilaian tentang pengorganisasian kelas oleh guru, dan (8) penilaian tentang evaluasi hasil belajar.

Indikator pada angket motivasi belajar dikembangkan berdasarkan beberapa pendapat terdahulu (Sardiman, 2012; Patimah, 2017; Lestari \& Yudhanegara, 2018), antara lain: (1) tekun belajar dan mengerjakan tugas matematika, (2) ulet dalam belajar dan mengerjakan tugas matematika, (3) menunjukan minat terhadap macam-macam masalah matematika, (4) lebih senang bekerja mandiri, dan (5) ada hasrat dan dorongan dari dalam diri untuk terus belajar hal-hal baru.

Sebelum digunakan kedua instrumen terlebih dahulu divalidasi secara teoritik dengan expert judgement. Validasi dilakukan oleh 2 orang validator ahli yaitu dosen pendidikan matematika FKIP Universitas Nusa Cendana. Validasi yang dilakukan mencakup tiga aspek yaitu substansi, konstruksi, dan bahasa yang digunakan. Berdasarkan catatan validator, baik instrumen angket persepsi siswa tentang guru matematika maupun angket motivasi belajar matematika, secara substansi disimpulkan layak untuk digunakan tanpa revisi. Namun dari sisi konstruksi dan bahasa terdapat beberapa catatan yang diberikan yang meliputi kesalahan pengetikan, tata bahasa, dan tanda baca. Selanjutnya instrumen direvisi berdasarkan catatan validator dan dikonsultasikan kembali kepada validator.

Setelah dinyatakan valid oleh kedua validator instrumen diujicobakan untuk menguji validitas empirik dan reliablitasnya dengan menggunakan SPSS 25. Berdasarkan hasil uji coba instrumen angket persepsi siswa tentang guru matematika diperoleh koefisien korelasi Product Moment Pearson yang terendah adalah $r_{X Y}=0.563$ untuk butir nomor 9 dan yang tertinggi adalah $r_{X Y}=$ 0.855 untuk butir nomor 12. Hal tersebut berarti untuk semua butir yang diujikan diperoleh $r_{X Y} \geq 0.40$, maka semua butir cukup baik/valid untuk digunakan (Lestari \& Yudhanegara, 2018). Sementara uji reliabilitas instrumen persepsi siswa tentang guru matematika menunjukkan bahwa koefisien reliabilitas Cronbach Alpha $r=0.968$, sehingga dapat dikatakan reliabilitas instumen sangat baik (Lestari \& Yudhanegara, 2018). Uji validitas instrumen angket motivasi belajar matematika menunjukkan bahwa koefisien korelasi Product Moment Pearson yang terendah adalah $r_{X Y}=0.507$ untuk butir nomor 14 dan yang tertinggi adalah $r_{X Y}=0.901$ untuk butir nomor 7. Hal tersebut berarti untuk semua butir yang diujikan diperoleh $r_{X Y} \geq 0.40$, maka semua butir cukup baik/valid untuk digunakan (Lestari \& Yudhanegara, 2018). Sementara uji reliabilitas instrumen persepsi siswa tentang guru matematika menunjukkan bahwa koefisien reliabilitas Cronbach Alpha $r=0.944$, sehingga dapat dikatakan reliabilitas instumen sangat baik (Lestari \& Yudhanegara, 2018). 
SSIM!|i'

Setelah instrumen diujicobakan dan dinyatakan valid dan reliabel, selanjutnya dilakukan pengumpulan data pada sampel penelitian. Skala yang digunakan dalam pembuatan instrumen menggunakan skala Likert dengan empat pilihan jawaban dalam setiap item yaitu SS (Sangat Sesuai), S (Sesuai), TS (Tidak Sesuai), STS (Sangat Tidak Sesuai). Penskoran yang dilakukan pada instrumen ini dilakukan secara langsung. Untuk item yang tergolong ke dalam item positif, maka skor yang diberikan untuk kategori $\mathrm{SS}=4, \mathrm{~S}=3, \mathrm{TS}=2$ dan STS adalah 1. Untuk item yang tergolong ke dalam item negatif, maka skor yang diberikan adalah $\mathrm{SS}=1, \mathrm{~S}=2, \mathrm{TS}=3$ dan STS $=4$.

Hasil pengolahan data angket tersebut kemudian dianalisis secara statistik inferensial dengan bantuan SPSS 25. Adapun analisis yang dilakukan meliputi uji prasyarat yaitu uji normalitas dan linearitas. Kemudian dilanjutkan dengan analisis regresi linear sederhana dengan bantuan SPSS 25.

\section{Hasil Penelitian dan Pembahasan}

\section{Hasil}

Hasil penelitian ini meliputi hasil angket persepsi siswa tentang guru matematika dan hasil angket motivasi belajar matematika siswa yang secara deskriptif disajikan pada tabel 1 dan tabel 2.

Tabel 1. Hasil Angket Persespi Siswa tentang Guru Matematika

\begin{tabular}{cc}
\hline Statistik & Skor \\
\hline Jumlah Sampel $(n)$ & 30 \\
X $_{\min }$ & 52 \\
$\mathrm{X}_{\max }$ & 74
\end{tabular}

$\bar{X}$

62,10

Std. Dev. $(s)$

5,66

Variansi $\left(s^{2}\right)$

32,02

Berdasarkan data pada tabel 1 di atas, dapat dilihat bahwa dari 30 siswa sebagai sampel penelitian, diperoleh skor minimum persepsi siswa tentang guru matematika adalah 52 dan skor maksimumnya adalah 74 . Sementara rata-rata skor yang diperoleh adalah 62,10 dengan standar deviasi dan variansi berturut-turut sebesar 5.66 dan 32.02.

Tabel 2. Hasil Angket Motivasi Belajar Matematika

\begin{tabular}{cc}
\hline Statistik & Skor \\
\hline Jumlah Sampel $(n)$ & 30 \\
$\mathrm{X}_{\min }$ & 51 \\
$\mathrm{X}_{\max }$ & 69 \\
$\bar{X}$ & 61,10 \\
Std. Dev. $(s)$ & 4,90 \\
Variansi $\left(s^{2}\right)$ & 24,02 \\
\hline
\end{tabular}

Berdasarkan data pada tabel 2 di atas, dapat dilihat bahwa dari 30 siswa sebagai sampel penelitian, diperoleh skor minimum motivasi belajar matematika siswa adalah 51 dan skor maksimumnya adalah 69. Sementara rata-rata skor yang diperoleh adalah 61,10 dengan standar deviasi dan variansi berturutturut sebesar 4.90 dan 24.02.

Berdasarkan data yang diperoleh dari angket persepsi siswa tentang guru matematika dan angket motivasi belajar matematika, dilakukan uji prasyarat analisis regresi linear sederhana yang meliputi uji normalitas dan uji linearitas dengan menggunakan SPSS 25.

Normalitas data diuji dengan Kolmogorov Smirnov Test menggunakan SPSS 25. Kaidah pengujian normalitas data dengan taraf signifikansi $\alpha=5 \%$ ditentukan 


\section{ASIMTOT: JURNAL KEPENDIDIKAN MATEMATIKA}

Volume 3 Nomor 2, Juni - November 2021, halaman 125 - 135

Tersedia Daring pada https://journal.unwira.ac.id/index.php/ASIMTOT

dengan aturan berikut. Jika $\mathrm{D}_{\text {hitung }}<\mathrm{D}_{\text {tabel }}$ atau $P$-value (nilai Sig.) $>\alpha$, maka terima $\mathrm{H}_{0}$ artinya data berdistribusi normal. Jika sebaliknya maka tolak $\mathrm{H}_{0}$, artinya data tidak berdistribusi normal. Hasil uji normalitas data disajikan pada tabel 3 .

Tabel 3. Hasil Uji Normalitas Data

\begin{tabular}{cccc}
\hline \multirow{2}{*}{ Variabel } & \multicolumn{3}{c}{ Kolmogorov-Smirnov } \\
\cline { 2 - 4 } & Statistic & Sig & $\begin{array}{c}\text { Keputusan } \\
\text { Uji }\end{array}$ \\
\hline Persepsi (X) & 0.110 & 0.200 & Terima $\mathrm{H}_{0}$ \\
Motivasi (Y) & 0.140 & 0.141 & Terima $\mathrm{H}_{0}$ \\
\hline
\end{tabular}

Berdasarkan hasil uji normalitas data pada tabel 3 diperoleh bahwa untuk variabel persepsi siswa tentang guru matematika nilai $\mathrm{D}_{\text {hitung }}<\mathrm{D}_{\text {tabel }}$ yaitu $0.110<0.24$ dan $P$-value (nilai Sig.) $>\alpha$ yaitu $0.200>0.05$. Sehingga $\mathrm{H}_{0}$ diterima yang berarti data persepsi siswa tentang guru matematika berdistribusi normal. Pada tabel 3 juga ditunjukkan bahwa untuk variabel motivasi belajar matematika nilai $\mathrm{D}_{\text {hitung }}<\mathrm{D}_{\text {tabel }}$ yaitu $0.140<0.24$ dan $P$-value (nilai Sig.) $>\alpha$ yaitu $0.141>0.05$. Sehingga $\mathrm{H}_{0}$ diterima yang berarti data motivasi belajar matematika berdistribusi normal.

Selanjutnya dilakukan uji linearitas data dengan uji $\mathrm{F}$ menggunakan SPSS 25. Kaidah pengujian linearitas data dengan taraf signifikansi $\alpha=5 \%$ ditentukan sebagai berikut. Jika $\mathrm{F}_{\text {hitung }}<\mathrm{F}_{\text {tabel }}$ atau $P$-value (nilai Sig.) $>\alpha$ maka terima $\mathrm{H}_{0}$ yaitu data berpola linear. Jika sebaliknya maka tolak $\mathrm{H}_{0}$, artinya data tidak berpola linear. Hasil uji linearitas data ditunjukkan pada tabel 4.

Tabel 4. Hasil Uji Linearitas Data

\begin{tabular}{cccc}
\hline $\begin{array}{c}\text { Persepsi (X) } \\
\text { terhadap } \\
\text { Motivasi (Y) }\end{array}$ & F & Sig & $\begin{array}{c}\text { Keputusan } \\
\text { Uji }\end{array}$ \\
\hline
\end{tabular}

\begin{tabular}{cccc}
$\begin{array}{c}\text { Deviation } \\
\text { from } \\
\text { Linearity }\end{array}$ & 1.189 & 0.381 & Terima $\mathrm{H}_{0}$ \\
\hline
\end{tabular}

Berdasarkan hasil uji linearitas data pada tabel 4 diperoleh bahwa nilai $\mathrm{F}_{\text {hitung }}<$ $\mathrm{F}_{\text {tabel }}$ yaitu $1.189<2.53\left(\mathrm{~F}_{0.05 ; 15 ; 13}\right)$ dan $P$ value (nilai Sig.) $>\alpha$ yaitu $0.381>0.05$. Sehingga $\mathrm{H}_{0}$ diterima yang berarti data terkait hubungan persepsi siswa tentang guru matematika terhadap motivasi belajar matematika berpola linear.

Berdasarkan hasil uji praysarat yang telah dilakukan maka disimpulkan bahwa data yang diperoleh memenuhi prasyarat analisi regresi linear sederhana. Selanjutnya dilakukan uji regresi linear sederhana dengan menggunakan SPSS 25. Ringkasan hasil uji yang dilakukan disajikan pada tabel 5 .

Tabel 5. Hasil Uji Regresi Linear Sederhana

\begin{tabular}{cc}
\hline Statistic & $\begin{array}{c}\text { Persespsi } \\
\text { terhadap } \\
\text { Motivasi }\end{array}$ \\
\hline Correlation Value & 0.702 \\
Coefficient of & 0.493 \\
Determination & 0.608 \\
Coefficient of Regression & 23.340 \\
Constant & 27.210 \\
F & 0.000 \\
Sig. &
\end{tabular}

Berdasarkan hasil yang disajikan pada tabel 5 dapat dilihat bahwa koefisien korelasi antara persepsi siswa tentang guru matematika dan motivasi belajar matematika adalah 0.702. Hal ini menunjukkan adanya hubungan yang kuat antara kedua variabel jika merujuk pada Guilford Empirical Rules (Lestari \& Yudhanegara, 2018). Selain itu, hasil tersebut juga menunjukkan hubungan yang positif atau berbanding lurus antara kedua variabel tersebut. Hasil analisis di atas 
ASIMTOT: JURNAL KEPENDIDIKAN MATEMATIKA

Volume 3 Nomor 2, Juni - November 2021, halaman 125 - 135

Tersedia Daring pada https://journal.unwira.ac.id/index.php/ASIMTOT

juga menunjukkan besarnya koefisien determinasi yaitu sebesar 0.493 yang mengindikasikan bahwa besarnya pengaruh variabel bebas persepsi siswa tentang guru matematika terhadap variabel terikat motivasi belajar matematika adalah sebesar $49.3 \%$, sementara $50.7 \%$ lainnya ditentukan oleh variabel lain yang tidak diteliti dalam penelitian ini.

Lebih lanjut koefisien regresi pada tabel 5 adalah sebesar 0.608 dengan konstanta sebesar 23.340. Sehingga dapat dinyatakan dalam model persamaan regresi $Y=23.340+$ $0.606 X+e$. Hal ini menunjukkan bahwa nilai konstan motivasi belajar matematika siswa adalah sebesar 23.340. Persamaan regresi tersebut juga mengidikasikan bahwa peningkatan nilai persepsi siswa tentang guru matematika sebesar 1 satuan maka nilai motivasi belajar matematika siswa juga meningkat sebesar 0.608 .

Tabel 5 di atas juga menunjukkan nilai $\mathrm{F}_{\text {hitung }}$ yaitu sebesar 27.210 dengan P-Value (nilai Sig.) sebesar 0.000. Karena $F_{\text {hitung }}>$ $\mathrm{F}_{\text {tabel }}=4.20\left(\mathrm{~F}_{0.05 ; 1 ; 28}\right)$ dan nilai Sig. $<\alpha=$ 0.05 , maka disimpulkan bahwa ada pengaruh yang signifikan persepsi siswa tentang guru matematika terhadap motivasi belajar matematika siswa.

\section{Pembahasan}

Aktivitas pembelajaran pada dasarnya melibatkan interaksi antara guru dan siswa. Interkasi tersebut tentu saja memungkinkan terbentuknya respon, pandangan, dan penilaian siswa tentang guru atau yang disebut juga dengan persepsi siswa. Persepsi siswa tentang guru merupakan salah satu aspek psikologi yang penting dalam diri siswa sebagai suatu respon terhadap performa, sikap, dan perilaku guru (Najichun dan Winarso, 2016). Dalam konteks pembelajaran, persepsi dapat dipandang sebagai proses kognitif yang menghasilkan pandangan, pendapat, dan respon terkait aktivitas pembelajaran yang diikuti siswa sebagai akibat dari informasi dan pengalaman yang diinderai atau dialami (Udil, 2020). Dalam hal ini, apa yang dipersepsikan siswa tentang guru merupakan hasil dari proses yang diinderai dan dialami siswa selama pembelajaran berlangsung. Dengan demikian, persepsi siswa tentang guru matematika dapat dipahami sebagai sebuah kesan, penilaian, dan pendapat siswa tentang performa guru matematika berdasarkan interpretasi siswa terhadap pengalaman yang dialami dalam aktivitas pembelajaran matematika.

Persepsi siswa tentang guru lebih lanjut akan membentuk dorongan dalam diri untuk belajar. Siswa yang mempunyai persepsi yang baik dan positif tentang gurnya akan merasa senang dan antusias untuk terlibat dalam proses pembelajaran bersama guru tersebut. Hal ini memungkinkan meningkatnya motivasi belajar matematika siswa. Sikap dan perilaku guru yang menyenangkan menurut siswa, akan menimbulkan persepsi positif dalam diri siswa yang memungkinkan motivasi belajar siswa meningkat dan berujung pada peningkatan prestasi belajar juga (Indiati, dkk., 2011). Sebaliknya, persepsi yang kurang baik akan membentuk motivasi yang kurang baik pula dalam belajar.

Berdasarkan hasil penelitian yang telah dianalisis di atas dapat dilihat bahwa secara deskriptif persepsi siswa tentang guru matematika pada siswa kelas VIII SMPN 5 Kupang Tengah berada pada kategori sedang 
ASIMTOT: JURNAL KEPENDIDIKAN MATEMATIKA

Volume 3 Nomor 2, Juni - November 2021, halaman 125 - 135

Tersedia Daring pada https://journal.unwira.ac.id/index.php/ASIMTOT

dengan rata-rata skor sebasar 62.10 . Sementara rata-rata skor motivasi belajar matematika siswa kelas VIII SMPN 5 Kupang tengah juga berada pada kategori sedang dengan rata-rata skor sebesar 61.10.

Hasil analisis data di atas menunjukkan adanya hubungan yang kuat dan positif antara persespsi siswa tentang guru matematika terhadap motivasi belajar matematika siswa kelas VIII SMPN 5 Kupang Tengah. Hasil penelitian ini sesuai dengan temuan Rikawati (2014) yang menenmukan adanya hubungan yang positif antara persepsi siswa tentang kepribadian guru matematika terhadap motivasi belajar matematika siswa kelas VIII MTs Negeri Balang-Balang Kec. Bontomarannu Kab. Gowa.

Adapun hasil penelitian di atas juga menunjukkan adanya pengaruh yang signifikan antara persepsi siswa tentang guru matematika terhadap motivasi belajar matematika siswa kelas VIII SMPN 5 Kupang Tengah. Hal ini ditunjukkan oleh nilai $\mathrm{F}_{\text {hitung }}=$ 27.210 yang lebih besar dari $\mathrm{F}_{\text {tabel }}=4.20$ $\left(\mathrm{F}_{0.05 ; 1 ; 28}\right)$. Signifikansi pengaruh tersebut juga terlihat dari P-Value (nilai Sig.) sebesar $0.000<\alpha=0.05$. Hal ini senada dengan temuan dalam penelitian Nasrulloh dan Susanti (2016) yang menemukan adanya pengaruh yang signifikan persepsi siswa tentang kepribadian guru terhadap motivasi belajar matematika siswa kelas VIII SMP Negeri 4 Merangin. Hal yang sama juga ditemukan oleh Rahmiyanti, dkk (2020) yang menemukan adanya pengaruh signifikan persepsi siswa tentang performa guru terhadap motivasi belajar.

\section{Simpulan dan Saran}

\section{Simpulan}

Berdasarkan hasil dan pembahasan yang telah dipaparkan di atas maka dapat disimpulkan bahwa terdapat hubungan yang kuat dan positif antara persepsi siswa tentang guru matematika terhadap motivasi belajar matematika siswa SMPN 5 Kupang Tengah. Lebih lanjut disimpulkan juga bahwa ada pengaruh yang signifikan persepsi siswa tentang guru matematika terhadap motivasi belajar matematika siswa SMPN 5 Kupang Tengah.

\section{Saran}

Adapun saran dan rekomendasi dari penelitian ini untuk guru matematika yaitu perlu memperhatikan dan meningkatkan kapasitas dan performanya sehingga dipersepsikan secara positif oleh siswa dan dapat mendorong terbentuknya motivasi belajar matematika siswa yang menunjang ketercapain prestasi belajar yang optimal. Selain itu, penelitian ini terbatas pada upaya untuk mengungkap hubungan dan pengaruh persepsi siswa tentang guru matematika terhadap motivasi belajar matematika secara kuantitatif, sedangkan kajian lebih lanjut terkait seperti apa pengaruh dan hubungan yang dimaksud secara kualitatif belum dilakukan. Oleh karena itu, saran bagi peneliti lain agar dapat melakukan penelitian lebih lanjut yang berupaya menggali secara kualitatif bagiamana motivasi siswa terbentuk berdasarkan persepsinya tentang guru matematika. 
ASIMTOT: JURNAL KEPENDIDIKAN MATEMATIKA

Volume 3 Nomor 2, Juni - November 2021, halaman 125 - 135

Tersedia Daring pada https://journal.unwira.ac.id/index.php/ASIMTOT

\section{Daftar Pustaka}

Ahmadi. (2017). Pengaruh Persepsi Siswa tentang Guru dan Minat Belajar terhadap Hasil Belajar Matematika Siswa Kelas X MIA MAN Wajo. Skripsi, tidak dipublikasikan. Fakultas Tarbiyah dan Keguruan UIN Alauddin.

Arikunto, S. (2010). Prosedur Penelitian Suatu Pendekatan Praktek. Jakarta: PT. Rineka Cipta.

Indiati, I., Muhtarom, Sarwono, T. J. (2011). Pengaruh Persepsi Siswa Kepada Guru Matematika dan Minat Belajar Matematika Siswa Terhadap Hasil Belajar Matematika Materi Himpunan pada Siswa Kelas VII Semester II SMP Negeri I Purwodadi Kabupaten Grobogan Tahun Pelajaran 2010/2011. Aksioma: Jurnal Matematika dan Pendidikan Matematika, 2 (1), 1-10.

Lestari, K. E. \& Yudhanegara, M. R. (2015). Penelitian Pendidikan Matematika: Panduan Praktis Menyusun Skripsi, Tesis, dan Karya Ilmiah dengan Pendekatan Kuantitatif, Kualitatif, dan Kombinasi Disertai dengan Model Pemebelajaran dan Kemampuan Matematis. Bandung: Refika Aditama.

Najichun, M. \& Winarso, W. (2016). Hubungan Persepsi Siswa tentang Guru Matematika dengan Hasil Belajar Matematika Siswa. Jurnal Psikologi Undip, 15 (2), 139-146.

Nasrulloh \& Susanti, A. (2016). Pengaruh Persepsi Siswa Tentang Kepribadian Guru Terhadap Motivasi Belajar Matematika Siswa. Mat-Edukasia: Jurnal Pendidikan Matematika, 1 (2), 22-27.

Oginni, I. O., Fadiji, A. E., \& Oginni, T. A. (2020). Students' Perception of Mathematics Teachers' Characteristics and their Attitude towards Mathematics in Ekiti State Southwest, Nigeria. Int Aca J Edu Lte. 1(6); 225-234.

Patimah. (2017). Pengaruh Motivasi Belajar dan Kemandirian Belajar terhadap Hasil Belajar Mata Pelajaran IPS Terpadu Pada Siswa Kelas VIII SMPN 10 Kota Jambi. Skripsi, tidak dipublikasikan. Universitas Jambi.

Rahmiyanti, R., Zaim, M. \& Refnaldi. (2020). Students' Perception on Teacher's Teaching Strategy and Its Effect Toward Students' Motivation in Learning English. Proceedings of the 7th International Conference on English Language and Teaching (ICOELT 2019), tanggal 4-5 November 2019. Padang: Universitas Negeri Padang.

Razak, F. (2016). The Effect of Cooperative Learning on Mathematics Learning Outcomes Viewed from Students' Learning Motivation. Journal of Research and Advances in Mathematics Education, 1 (1), 49-55.

Rikawati. (2014). Pengaruh Persepsi Siswa tentang Kepribadian Guru Matematika terhadap Motivasi Belajar Matematika Siswa Kelas VIII MTS Negeri BalangBalang. Skripsi, tidak dipublikasikan. Fakultas Tarbiyah dan Keguruan UIN Alauddin.

Sahidin, L. \& Jamil, D. (2013). Pengaruh Motivasi Berprestasi dan Persepsi Siswa Tentang Cara Guru Mengajar Terhadap Hasil Belajar Matematika. Jurnal Pendidikan Matematika, 4 (2), 212-223. Sardiman, A. M. (2012). Interaksi dan Motivasi Belajar Mengajar. Jakarta: Raja Grafindo Persada.

Sugiyono. (2013). Metode Penelitian Pendidikan Pendekatan Kuantitatif, Kualitatif, dan R\&D. Bandung: Alfabeta. 
ASIMTOT: JURNAL KEPENDIDIKAN MATEMATIKA

Volume 3 Nomor 2, Juni - November 2021, halaman 125 - 135

Tersedia Daring pada https://journal.unwira.ac.id/index.php/ASIMTOT

Syaripah. (2016). Pengaruh Persepsi Pembelajaran Matematika Terhadap Motivasi Belajar Siswa dalam Bidang Matematika di Sekolah SMA Negeri 1 Curup Timur T.P 2015/2016. Jurnal EduTech, 2 (2), 117-131.

Udil, P. A. (2020). Persepsi Mahasiswa Tentang Perkuliahan Berbasis ELearning dengan Menggunakan Schoology. Fraktal: Jurnal Matematika dan Pendidikan Matematika, 1 (1), 7991. 